\title{
Host landing and diel activity of potent vectors of bluetongue disease, Culicoides oxystoma and Culicoides peregrinus
}

\author{
Shuddhasattwa Maitra Mazumdar \\ The University of Burdwan \\ BISWAJIT MONDAL \\ The University of Burdwan

\section{Surajit Kar} \\ The University of Burdwan \\ Abhijit Mazumdar ( $\sim$ abhijitbu02@gmail.com ) \\ The University of Burdwan
}

\section{Research Article}

Keywords: Culicoides, preferential landing, diel activity, biting activity, cattle

Posted Date: March 28th, 2022

DOI: https://doi.org/10.21203/rs.3.rs-1038977/v2

License: (c) (i) This work is licensed under a Creative Commons Attribution 4.0 International License. Read Full License 


\section{Abstract \\ Background}

The spread of bluetongue virus (BTV) depends on the vectorial ability of Culicoides affecting the susceptible host. Animal farms in West Bengal have reported prevalence of potent vectors of BTV (C. oxystoma, $C$. peregrinus and $C$. fulvus). Additionally, high seroprevalence of BTV was also reported from this cattle dense region. To minimize the risk of disease outbreak a strategy to reduce the exposure of cattle to midges bite is necessary. Therefore host-seeking activity of two important potent vectors, $C$. oxystoma and $C$. peregrinus on cattle were studied in two farm sites of West Bengal, India.

\section{Methods}

The study was done in 2018-19 comprising 297 hours of collection over 27 nights. A comparison was made between the catches obtained by mouth aspirator and light trap. Hourly collections of Culicoides were taken directly from cattle (oral aspirator) as well as light trap was operated in close vicinity of cattle at a different shed.

\section{Results}

A total of 15,456 Culicoides belonging to $C$. oxystoma, $C$. peregrinus and $C$. fulvus were collected in light trap and aspirator during the study. 8,758 midges were collected by aspirator, whereas 6,698 individuals were collected in light trap. The following species were aspirated: $C$. peregrinus and $C$. oxystoma; while the light trap catches consisted of $C$. fulvus, $C$. oxystoma and $C$. peregrinus. Light trap collection exhibited crepuscular activity whereas aspirator collection was maximum between 4:00 hr and 5:00 hr. Maximum landing of midges was observed in the neck and hump region of the cattle.

\section{Conclusion}

It was observed that the preferred time of feeding of $C$. peregrinus and $C$. oxystoma on cattle were early morning hours though midges were ubiquitous from dusk to dawn. Surprisingly the preferential landing of the two vectors were mostly restricted to the neck and hump region of the cattle. The results obtained during the study warrants further insight into the factors influencing the landing site by the vectors which may be useful biological data in disease management and draw effective deterrent strategies.

\section{Background}

Among the hematophagous genera, Culicoides have assumed significance and notoriety worldwide due to its ability to transmit a wide range of pathogens of public and veterinary importance [1]. Presently India records 535.8 million as major farm animals i.e cattle, buffalo, poultry, sheep and goat including indigenous and exotic breeds, with a total bovine population of 302.8 million (buffalo, cattle, mithun, yak) [2]. The presence of large and diverse populations of livestock increases transmission risk of bluetongue virus (BTV) by Culicoides which may lead to outbreak of bluetongue (BT). This virus causes BT in goats, sheep, cattle and other small and wild ruminants [3]. Although the disease was dominant in temperate zones, introduction of non-native breeds in virus endemic tropical and subtropical zones also caused BT outbreak [4]. The spread of range of BTV in the temperate was also attributed to global warming [5]. Presently seroprevalence of BTV has been reported across all the Indian states [6]. The BT outbreak has been witnessed frequently owing to the significant density of livestock, high prevalence of the Culicoides along with conducive climatic conditions helping in propagation of vectors and the virus $[7,8]$.

BTV was first recorded from the state of Maharashtra [9] and also occurrences of BTV from Indian states covering western, northern and southern regions followed $[10,11]$. Although eastern and north eastern India is yet to witness an outbreak, high seroprevalence in livestock has appeared in several scientific articles [11, 12]. Presently 22 of the 28 serotypes (worldwide) have been recorded from India [13]. Moreover BTV seropositivity in different animals depicts $34.0 \%$ in bufalo, $16.0 \%$ in caml, $38.0 \%$ in catle, $43.0 \%$ in goa, $39.0 \%$ in shep and $66.0 \%$ in mitun [13]. The state of West Bengal shares $6.9 \%$ of total livestock population comprising of $8.3 \%$ cattle, $0.8 \%$ sheep and $10.9 \%$ goats' population. The economy of West Bengal, especially in Burdwan district was agriculture based (mixed farming) in which livestock and animal husbandry plays a pivotal role. The villagers form a cluster of self help groups (SHG) which market livestock products to generate revenue [14]. The seroprevalence in goat (67.0 \%), shee (57.7 \%) and cttle (52.0\%) has ben reported across 7 districts of West Bengal [15, 16]. Despite such high seroprevalence, BT outbreak remains unreported from West Bengal [17]. BT outbreak and its economic implications has been well documented from the southern Indian states, however, there remains critical knowledge gaps and understanding of biology of the potent vector species prevalent in this tropical region. Few studies on biology, ecology and taxonomy of the Culicoides spp. were carried out $[8,17]$. It has been reported prevalence of 7 putative vectors $C$. oxystoma, $C$. fulvus, $C$. orientalis, $C$. dumdumi, C. imicola, C. peregrinus and C. brevitarsis from southern India [18]. In the eastern state of West Bengal, $C$. fulvus, $C$. peregrinus and $C$. oxystoma were the prevalent species in mixed farms and cattle sheds $[8,17]$ thereby posing considerable risk in the spread of disease. Further a 
coloured LED light trap based extensive surveillance program was also conducted in the same site to ascertain the prevalence of the aforesaid species in the cattle sheds [8].

Information available on host seeking activity, ecology and biology of Culicoides are limited across the globe [19, 20]. The aforesaid information was imperative for implementation of control measures in disease epidemiology [20]. Although the disease causing pathogens vectored by Culicoides were a matter of concern, relatively scant information on its bionomics exists in India [18] and Europe [20, 21, 22]. In the light of forecasting disease transmission, limited information on the host-vector association has led to assumptions that all the Culicoides species prevalent in the cattle sheds fed on host with equal facility on which various predictions were based [21]. Difficulty in aspirating Culicoides from the host body also limits studies on host seeking activity of the Culicoides [19].

In the present study the catch data obtained by two different methods (light trap and aspirator) were evaluated and compared in order to separate two adult activity of Culicoides spp. in real time: flight activity and biting activity. The midges may undertake flight for foraging, mating, seeking of resting place or to oviposit. Biting activity points to the association of vectors to its host, probable route of transmission of disease depicted. The two study sites were selected at Burdwan district of West Bengal due to report of seroprevalence of BTV from this region [12] as well as high seasonal abundance of potent vector species of Culicoides associated with livestock from this district [17]. Moreover, the evaluation enables validation of the time and preferential landing of Culicoides on cattle body parts which is critical at farmer's level to reduce the host-vector contact.

\section{Materials And Methods}

\section{Study site}

This investigation was carried out in two rural villages of West Bengal $51 \mathrm{~km}$ apart i) Dharan ( $\left.\mathrm{DH} ; 23^{\circ} 02^{\prime} 57.7^{\prime \prime} \mathrm{N}, 87^{\circ} 51^{\prime} 47.5^{\prime \prime} \mathrm{E}\right)$ and ii) SahibganjTantipara (ST; $\left.23^{\circ} 44^{\prime} 29.14^{\prime \prime} \mathrm{N}, 87^{\circ} 82^{\prime} 76.56 " \mathrm{E}\right)$. The biting midges were trapped throughout the seasons in DH during May to October, 2018 and in April to June, 2019; and in ST from May to October, 2018. In West Bengal high abundance of midges has been observed during April to October after which the population declines [17]. At ST village site, 12 night collections were made i.e., two catches/month, whereas in $\mathrm{DH}$ village site, three monthly collections were done (excepting for the months of October, April and June where single collections/every month). A total of 27 night catch data (297 hrs of collection) were considered for both the sites. In both the sites, the sheds housing the cattle were made of mud-brick adjoining to household. Geographically the villages are situated amidst agricultural fields in which extensive rice cultivation is practiced throughout the year, water logging even during dry seasons predominantly rice growing areas of West Bengal. Most households maintain livestock animals for their economic sustenance. It experiences tropical climate with annual rainfall of 1,496 mm. The hygiene conditions were compromised within and outside the perimeter of the animal sheds as dung heaps and paddy straws were dumped. In ST, the cattle sheds were located on the embankment of a pond. Moreover, the drainage system of the village was found to empty into the pond. For this study one cattle shed at DH and two cattle sheds at ST were chosen. The two farms at ST consisted of single white cattle each and at DH two white cattle were present. The farms were chosen in areas (district) where seroprevalence of BTV has been reported. Moreover high cattle density with prevalence of putative vectors of bluetongue ( $C$. oxystoma, $C$. peregrinus and $C$. fulvus) led to selection of farms.

\section{Description of collection}

The adults that landed on the host body surface was retrieved by aspirators (oral \& mechanical) and flying adults were trapped by UV LED light traps $[23,8]$ installed at close vicinity of cattle within the shed. Adults were aspirated covering various parts of the body surface of a white coloured adult cow. For our convenience the entire body surface of the cattle was subdivided [24] following the studies of [20] and [21]. Catches made were labeled as follows: head $(\mathrm{H} 1)$, neck $(\mathrm{H} 2)$, hump $(\mathrm{H} 3)$, back $(\mathrm{H} 4)$, leg $(\mathrm{H} 5)$, belly $(\mathrm{H} 6)$, hip $(\mathrm{H} 7)$ (Fig. 1). Each catch duration was restricted to 10 minutes/hour. Entire process of aspiration was initiated at $18.00 \mathrm{hr}$ in the evening that continued up to $6.00 \mathrm{hr}$ in the morning (12 hours per diem). The catch period (designated T1 hr to T11 hr) as followed: T1: 18.00-19.00, T2: 19.00-20.00, T3: 20.00-21.00, T4: 21.00-22.00, T5: 23.00-00.00, T6: 00.00-01.00, T7: 01.00-02.00, T8: 02.00-03.00, T9: 03.00-04.00, T10: 04.00-05.00, T11: 05.00-06.00. Prior to initiation of the study, a pilot trial was conducted using a mechanical and mouth aspirator for collection of midges from cattle. It was observed that mouth aspirator was more effective in collection compared to the mechanical aspirator for Culicoides. During the study entire sampling was done using mouth aspirator at both the sites (DH \& ST). In each collection, midges from single white cattle were aspirated by a person. Half an hour before the sampling, one cattle was kept in the shed and others were removed. The midges were visually located on the body of the white cattle and collected with mouth aspirator. For easy visualization of midges on the cattle a $4 \mathrm{~W}$ dim light was used during the collection. At ST, UV LED light trap was operated within the cattle shed $200 \mathrm{~m}$ apart from the shed where aspiration based collections were done. Culicoides species were mounted on glass slides and identified on the basis of salient morphological characters [25]. The females were age graded on the basis of abdominal pigmentation [26]. However in the present study the unfed nulliparous and unfed parous collections were clustered as non-engorged and rest as engorged. Gravid females were mentioned.

\section{Statistical Analysis}

A logistic regression was done on the proportion of engorged and non engorged females to justify the effects of time and site on host landing. The logistic regression was carried following the binomial GLM with logit link, using time and site as the explanatory variables on the assumptions of generalized linear model (GLM). The logistic regression equation form: $(y)=1 /\left(1+\exp \left(-\left(a+b_{1} x_{1}+b_{2} x_{2}+b_{3} x_{3}\right)\right)\right.$; where the explanatory variables, $x_{1}$, $x_{2}$ and $x_{3}$, represented the time of landing of Culicoides on host, site of landing on host and interaction between the two components respectively and $y$ 
was the response variable. The regression analysis was performed on the assumptions that the landing of non-engorged and engorged Culicoides follow binomial distribution ( $n, p)$ with $n$ replicates for each set of independent variables (time of landing, site of landing on host and interaction between host landing and time). Maximum likelihood method has been used as a measure to estimate the logit linked parameters through statistical software. Using the value of Wald's Chi square, the parameter of the models were tested for the significance at $P=0.05$ level.

\section{Results}

A total of 15,456 Culicoides spp. were collected during the study at both the sites. In DH, of the total 3994 individuals collected, $C$. oxystoma females were 1,924 individuals which were further categorized into 1,315 non-engorged and 609 engorged individuals. Culicoides peregrinus females consisted of 2,070 individuals of which 1,192 non-engorged and 878 engorged individuals (Table 1a). In ST, a total catch of $C$. oxystoma were 2,119 individuals comprised of 1,220 non-engorged, 899 engorged individuals. Culicoides peregrinus comprised of 2,645 individuals, of which 1015 were non-engorged and 1,630 engorged females (Table $1 \mathrm{~b}$ ). In ST collections, the following species were aspirated: $C$. peregrinus and $C$. oxystoma; however the light trap catches consisted of $C$. fulvus, $C$. oxystoma and $C$. peregrinus. The total Culicoides caught through aspiration were 4,764 compared to light trap catch of 6,698 individuals (both female and male) (Fig. 2a; 2b). Significant numbers of Culicoides individuals landed on the upper portion of the cattle, while very few individuals landed on the belly and legs. Landing of Culicoides was limited to hip due to continuous tail whipping, licking and kicking reflexes of the cattle. It appeared that a period of 30-40 min i.e. between 4:00 hr and 5:00 hr (dawn) was the actual feeding window of the $C$. oxystoma and $C$. peregrinus attacking the cattle (Fig. 3). During the feeding intervals Culicoides females were observed to swarm on the host and they attacked the cattle with equal intensity. The proportion of engorged C. peregrinus aspirated were more (42.42\%) compared to $C$. oxystoma (31.65\%) (Fig. 4 a and 4b). 
Table 1

a. Number of $C$. oxystoma and $C$. peregrinus collected from body parts of cattle at various time (hr) in Dharan, West Bengal. $\mathrm{H} 1$, head; $\mathrm{H} 2$, neck; $\mathrm{H} 3$, hump; $\mathrm{H} 4$, back; $\mathrm{H} 5$, leg; $\mathrm{H} 6$, belly; $\mathrm{H} 7$, hip of the cattle.

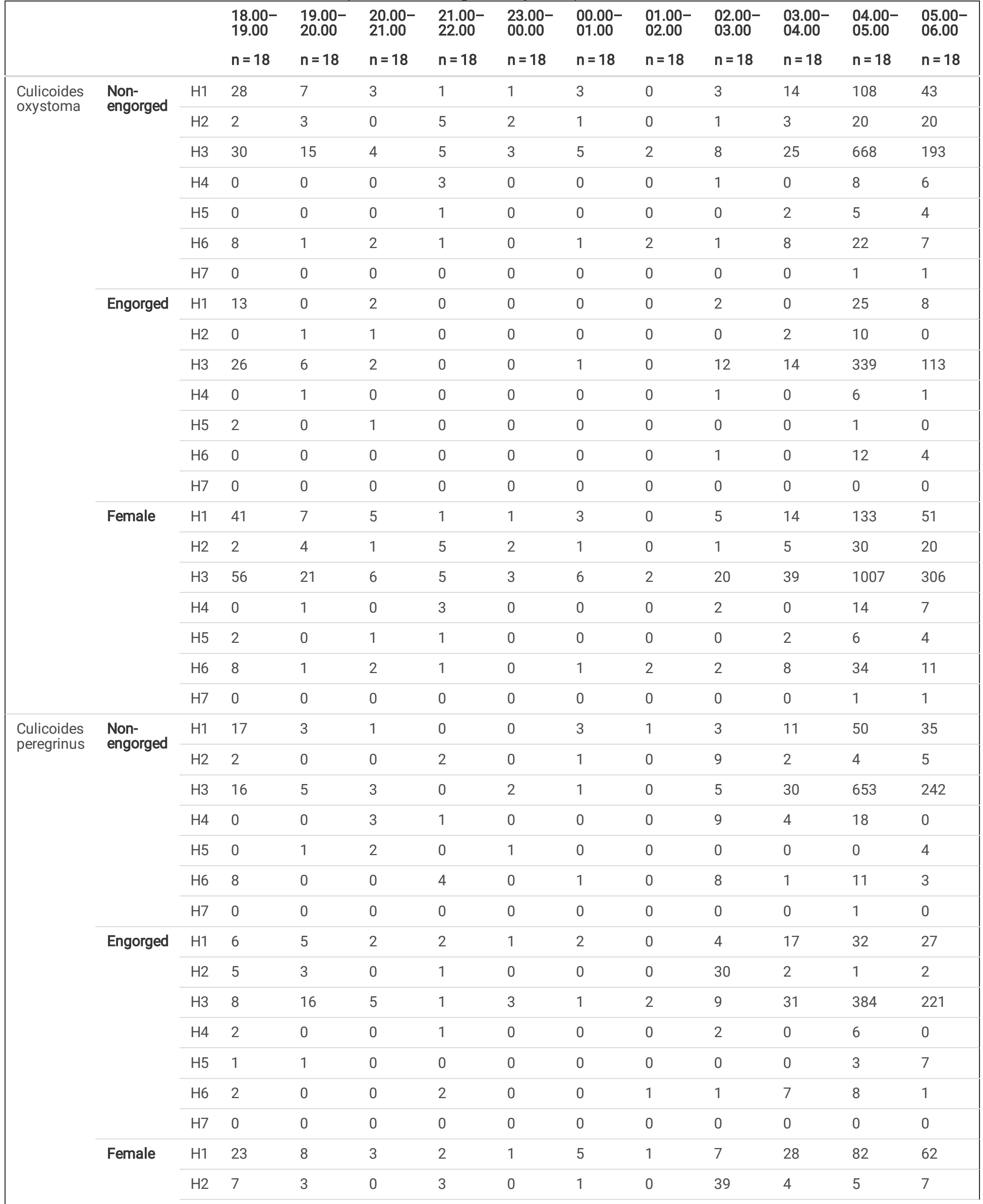




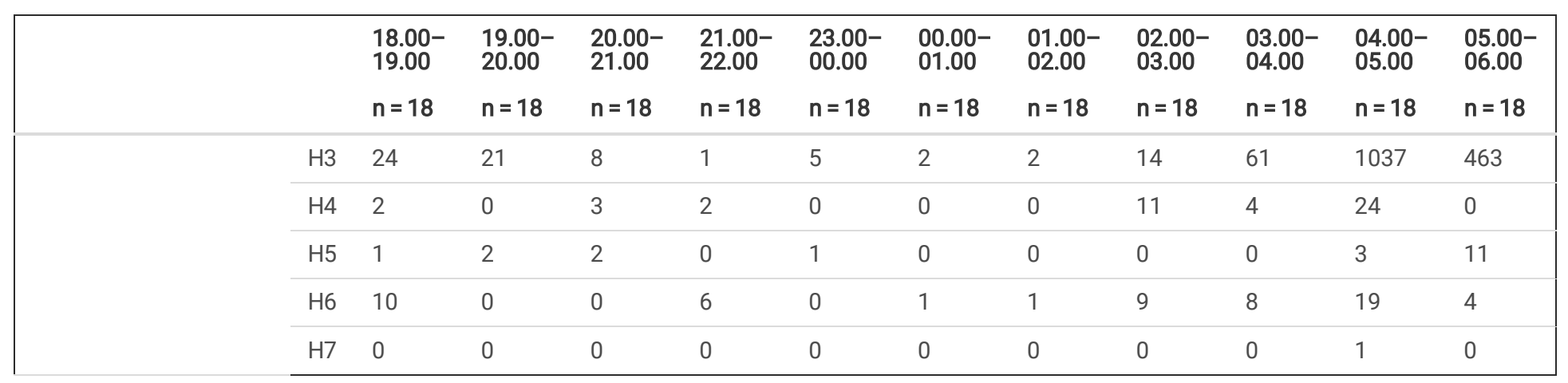


Table 1

b. Number of $C$. oxystoma and $C$. peregrinus collected from body parts of cattle at various time (hr) in Dharan, West $\mathrm{Bengal}$. $\mathrm{H} 1$, head; $\mathrm{H} 2$, neck; $\mathrm{H} 3$, hump; H4, back; $\mathrm{H} 5$, leg; H6, belly; $\mathrm{H} 7$, hip of the cattle.

\begin{tabular}{|c|c|c|c|c|c|c|c|c|c|c|c|c|c|}
\hline & & & $\begin{array}{l}18.00- \\
19.00 \\
n=12\end{array}$ & $\begin{array}{l}19.00- \\
20.00 \\
n=12\end{array}$ & $\begin{array}{l}20.00- \\
21.00 \\
n=12\end{array}$ & $\begin{array}{l}21.00- \\
22.00 \\
n=12\end{array}$ & $\begin{array}{l}23.00- \\
00.00 \\
n=12\end{array}$ & $\begin{array}{l}00.00- \\
01.00 \\
n=12\end{array}$ & $\begin{array}{l}01.00- \\
02.00 \\
n=12\end{array}$ & $\begin{array}{l}02.00- \\
03.00 \\
n=12\end{array}$ & $\begin{array}{l}03.00- \\
04.00 \\
n=12\end{array}$ & $\begin{array}{l}04.00- \\
05.00 \\
n=12\end{array}$ & $\begin{array}{l}05.00- \\
06.00 \\
n=12\end{array}$ \\
\hline \multirow{21}{*}{$\begin{array}{l}\text { Culicoides } \\
\text { oxystoma }\end{array}$} & \multirow{7}{*}{$\begin{array}{l}\text { Non- } \\
\text { engorged }\end{array}$} & $\mathrm{H} 1$ & 16 & 2 & 0 & 3 & 0 & 0 & 1 & 2 & 2 & 20 & 15 \\
\hline & & $\mathrm{H} 2$ & 48 & 12 & 7 & 1 & 3 & 3 & 15 & 7 & 39 & 639 & 89 \\
\hline & & H3 & 13 & 5 & 1 & 0 & 0 & 2 & 2 & 1 & 3 & 117 & 40 \\
\hline & & $\mathrm{H} 4$ & 2 & 0 & 1 & 0 & 0 & 0 & 0 & 0 & 1 & 4 & 0 \\
\hline & & H5 & 4 & 1 & 0 & 1 & 1 & 1 & 1 & 1 & 1 & 69 & 5 \\
\hline & & $\mathrm{H} 6$ & 1 & 0 & 2 & 0 & 0 & 0 & 0 & 0 & 1 & 12 & 2 \\
\hline & & $\mathrm{H} 7$ & 1 & 0 & 0 & 0 & 0 & 1 & 0 & 0 & 0 & 0 & 0 \\
\hline & \multirow[t]{7}{*}{ Engorged } & $\mathrm{H} 1$ & 7 & 0 & 0 & 0 & 0 & 0 & 0 & 0 & 1 & 11 & 9 \\
\hline & & $\mathrm{H} 2$ & 38 & 28 & 29 & 2 & 0 & 7 & 2 & 4 & 67 & 359 & 59 \\
\hline & & $\mathrm{H} 3$ & 38 & 35 & 12 & 1 & 1 & 1 & 0 & 3 & 14 & 78 & 56 \\
\hline & & $\mathrm{H} 4$ & 0 & 0 & 0 & 0 & 0 & 0 & 0 & 0 & 0 & 1 & 0 \\
\hline & & H5 & 1 & 0 & 0 & 0 & 0 & 0 & 0 & 0 & 0 & 16 & 0 \\
\hline & & $\mathrm{H} 6$ & 0 & 0 & 3 & 0 & 0 & 0 & 0 & 0 & 0 & 8 & 6 \\
\hline & & $\mathrm{H} 7$ & 0 & 0 & 0 & 0 & & 0 & 0 & 0 & 0 & 0 & 2 \\
\hline & \multirow[t]{7}{*}{ Female } & $\mathrm{H} 1$ & 23 & 2 & 0 & 3 & 0 & 0 & 1 & 2 & 3 & 31 & 24 \\
\hline & & $\mathrm{H} 2$ & 86 & 40 & 36 & 3 & 3 & 10 & 17 & 11 & 106 & 998 & 147 \\
\hline & & $\mathrm{H} 3$ & 51 & 40 & 13 & 1 & 1 & 3 & 2 & 4 & 17 & 195 & 96 \\
\hline & & $\mathrm{H} 4$ & 2 & 0 & 1 & 0 & 0 & 0 & 0 & 0 & 1 & 5 & 0 \\
\hline & & H5 & 5 & 1 & 0 & 1 & 1 & 1 & 1 & 1 & 1 & 85 & 5 \\
\hline & & $\mathrm{H} 6$ & 1 & 0 & 5 & 0 & 0 & 0 & 0 & 0 & 1 & 20 & 8 \\
\hline & & $\mathrm{H} 7$ & 1 & 0 & 0 & 0 & 0 & 1 & 0 & 0 & 0 & 0 & 2 \\
\hline \multirow{17}{*}{$\begin{array}{l}\text { Culicoides } \\
\text { peregrinus }\end{array}$} & \multirow{7}{*}{$\begin{array}{l}\text { Non- } \\
\text { engorged }\end{array}$} & $\mathrm{H} 1$ & 6 & 0 & 0 & 1 & 0 & 0 & 0 & 1 & 0 & 5 & 11 \\
\hline & & $\mathrm{H} 2$ & 56 & 4 & 15 & 3 & 0 & 4 & 1 & 31 & 28 & 603 & 27 \\
\hline & & $\mathrm{H} 3$ & 4 & 4 & 0 & 1 & 2 & 1 & 1 & 16 & 13 & 82 & 17 \\
\hline & & $\mathrm{H} 4$ & 0 & 0 & 0 & 0 & 0 & 0 & 0 & 2 & 0 & 0 & 2 \\
\hline & & H5 & 8 & 2 & 0 & 0 & 0 & 0 & 0 & 0 & 0 & 53 & 3 \\
\hline & & $\mathrm{H} 6$ & 1 & 2 & 2 & 0 & 0 & 0 & 0 & 0 & 1 & 2 & 0 \\
\hline & & $\mathrm{H} 7$ & 0 & 0 & 0 & 0 & 0 & 0 & 0 & 0 & 0 & 0 & 0 \\
\hline & \multirow[t]{7}{*}{ Engorged } & $\mathrm{H} 1$ & 6 & 0 & 0 & 0 & 0 & 0 & 0 & 1 & 8 & 12 & 20 \\
\hline & & $\mathrm{H} 2$ & 10 & 8 & 19 & 10 & 0 & 5 & 1 & 22 & 230 & 815 & 73 \\
\hline & & $\mathrm{H} 3$ & 51 & 70 & 2 & 7 & 1 & 3 & 1 & 4 & 61 & 81 & 36 \\
\hline & & $\mathrm{H} 4$ & 1 & 1 & 0 & 0 & 0 & 0 & 0 & 0 & 0 & 5 & 0 \\
\hline & & H5 & 9 & 0 & 0 & 0 & 1 & 0 & 0 & 3 & 0 & 29 & 5 \\
\hline & & $\mathrm{H} 6$ & 0 & 0 & 1 & 0 & 0 & 0 & 0 & 1 & 0 & 16 & 1 \\
\hline & & $\mathrm{H} 7$ & 0 & 0 & 0 & 0 & 0 & 0 & 0 & 0 & 0 & 0 & 0 \\
\hline & \multirow[t]{3}{*}{ Female } & $\mathrm{H} 1$ & 12 & 0 & 0 & 1 & 0 & 0 & 0 & 2 & 8 & 17 & 31 \\
\hline & & $\mathrm{H} 2$ & 66 & 12 & 34 & 13 & 0 & 9 & 2 & 53 & 258 & 1418 & 100 \\
\hline & & H3 & 55 & 74 & 2 & 8 & 3 & 4 & 2 & 20 & 74 & 163 & 53 \\
\hline
\end{tabular}




\begin{tabular}{|c|c|c|c|c|c|c|c|c|c|c|c|}
\hline & $\begin{array}{l}18.00- \\
19.00 \\
n=12\end{array}$ & $\begin{array}{l}19.00- \\
20.00 \\
n=12\end{array}$ & $\begin{array}{l}20.00- \\
21.00 \\
n=12\end{array}$ & $\begin{array}{l}21.00- \\
22.00 \\
n=12\end{array}$ & $\begin{array}{l}23.00- \\
00.00 \\
n=12\end{array}$ & $\begin{array}{l}00.00- \\
01.00 \\
n=12\end{array}$ & $\begin{array}{l}01.00- \\
02.00 \\
n=12\end{array}$ & $\begin{array}{l}02.00- \\
03.00 \\
n=12\end{array}$ & $\begin{array}{l}03.00- \\
04.00 \\
n=12\end{array}$ & $\begin{array}{l}04.00- \\
05.00 \\
n=12\end{array}$ & $\begin{array}{l}05.00- \\
06.00 \\
n=12\end{array}$ \\
\hline $\mathrm{H} 4$ & 1 & 1 & 0 & 0 & 0 & 0 & 0 & 2 & 0 & 5 & 2 \\
\hline $\mathrm{H} 5$ & 17 & 2 & 0 & 0 & 1 & 0 & 0 & 3 & 0 & 82 & 8 \\
\hline $\mathrm{H} 6$ & 1 & 2 & 3 & 0 & 0 & 0 & 0 & 1 & 1 & 18 & 1 \\
\hline $\mathrm{H} 7$ & 0 & 0 & 0 & 0 & 0 & 0 & 0 & 0 & 0 & 0 & 0 \\
\hline
\end{tabular}

Table 1c. Collection of Culicoides spp. using sampling methods (Aspirator \& UV light trap) at Sahibganj-Tantipara, West Bengal

\begin{tabular}{llll} 
& & Aspirator & UV LED light trap \\
& & $\mathrm{n}=12$ & $\mathrm{n}=12$ \\
\hline \multirow{3}{*}{ C. oxystoma } & Male & 0 & 83 \\
\cline { 2 - 4 } & Female & 2119 & 1146 \\
\cline { 2 - 4 } & Non-engorged & 1220 & 652 \\
\cline { 2 - 4 } & Engorged & 899 & 435 \\
\cline { 2 - 4 } C. peregrinus & Gravid & 0 & 59 \\
\cline { 2 - 4 } & Male & 0 & 46 \\
\cline { 2 - 4 } & Female & 2645 & 5197 \\
\cline { 2 - 4 } & Non-engorged & 1015 & 3718 \\
\cline { 2 - 4 } C. fulvus & Engorged & 1630 & 1418 \\
\cline { 2 - 4 } & Gravid & 0 & 61 \\
\cline { 2 - 4 } & Male & 0 & 14 \\
\cline { 2 - 4 } & Female & 0 & 212 \\
\cline { 2 - 4 } & Non-engorged & 0 & 67 \\
\cline { 2 - 3 } & Engorged & 0 & 143 \\
\cline { 2 - 4 } & Gravid & 0 & 2 \\
\hline
\end{tabular}

\section{Dharan}

GLM with logit link depicted that the following parameters were significant at $\mathrm{p}<0.05$ for all the observations: engorged $C$. oxystoma exhibited significance for preferential landing on host $\left(X^{2}=9.3\right)$ with time $\left(X^{2}=11.44\right)$; non-engorged females preferred hump and neck for landing at specific time interval $\left(x^{2}=6.2\right)$. Similarly, engorged $C$. peregrinus exhibited preference for specific body part of the cattle $\left(x^{2}=14.75\right)$ with time $\left(x^{2}=7.3\right)$ and for non-engorged similar observation was noted with respect to time $\left(\chi^{2}=8.6\right)$ and choice of the individuals to descend at specific body part $\left(\chi^{2}=3.9\right)$.

\section{Sahebganj-Tantipara (ST)}

For $C$. oxystoma, the binomial GLM with logit link exhibited that the following parameters were significant at $p<0.05$ level for all the variables in each observation: for engorged individuals notable variance in response has been observed with respect to preferential host landing against time $\left(x^{2}=\right.$ 3.976). Similar pattern for non engorged individuals has been observed: variation in preference for landing on different body parts of host $\left(\chi^{2}=15.31\right)$ has been exhibited. For engorged $C$. peregrinus females the factors were observed significant for interaction between choice of landing with time $\left(\chi^{2}=\right.$ $10.81)$ and similarly for non-engorged females also $\left(\chi^{2}=14.61\right)$.

\section{Discussion}

The Culicoides species investigated in this study were reported to be vectors of important diseases associated with farm animals' worldwide [17]. Shielding of animals from attack of female Culicoides may be adopted as a measure to interrupt disease transmission hence information on peak activity of Culicoides from this region of the world will be useful in disease management strategies [17]. The landing time and site of females belonging to $C$. oxystoma and $C$. peregrinus on the cattle in the early morning for the purpose of obtaining blood meal was observed. However, $C$. 
fulvus has been reported only in a light trap from one of the study sites thereby raising doubts on the host preference of the species. The aspirator based study validated the diel activity of the $C$. oxystoma and $C$. peregrinus. Significant proportion of engorged females in the study justified the usage of aspirator to intercept the host-seeking females. Moreover the present study ascertained that cattle not only attracted Culicoides but constituted one of the significant hosts. Culicoides oxystoma and $C$. peregrinus were known to be one of the most prevalent species across India, from which the BTV serotypes have been isolated $[27,28]$ and also were enlisted as potent vectors of BTV from the subcontinent [18]. Moreover both the species were reported to be most abundant in cattle sheds of West Bengal [17] thereby contributing to the significance of the study. High proportion of engorged $C$. peregrinus and $C$. oxystoma feeding on the cattle suggests active blood-seeking behaviour of the species, which agrees with the opinion regarding fierceness of $C$. peregrinus [29]. Culicoides oxystoma has been recognized as potential vectors of BTV from India [27] and Indonesia [30]. Japan has reported $C$. oxystoma as potent vector of Akbane virus [31, 32] and of epizootic hemorrhagic disease virus from Israel [33]. Moreover [34] has reported involvement of $C$. oxystoma in transmission of African horse sickness virus (AHSV) from Senegal.

The proportion of engorged to non-engorged females aspirated ascertains landing of Culicoides on host but does not warrant feeding. It was noted that $45 \%$ of the total midges landing actually fed on the cattle; the finding substantiated the conclusion drawn on activity of Culicoides midges from Ireland [35]. The work in Ireland was carried out as an extension of the project work on aetiology of sweet itch in horse. During the study, predominantly C. obsoletus and $C$. dewulfi were collected using aspirator from host body. Other species were $C$. pulicaris and $C$. nebeculosus. The study reported $40.3 \%$ of midges actually fed of the total landing (i.e., 4097 Culicoides fed of the total landing of 10,178). However preferential landing site of Culicoides was different in both the studies due to different host.

The pattern of distribution observed from the light trap catch data to be non-linear random with two or more peaks observed between dusk and dawn. The prevalence of the Culicoides in light trap within cattle shed validates more of their crepuscular nature. Nonetheless, Culicoides were observed to be prevalent in resting conditions in the cracks, crevices, walls, and roof within the shed housing cattle throughout the 24 hour period. However contrasting their nocturnal peaks between dusk and dawn, biting activity of Culicoides was limited only to early morning (4:00-5:00 hr). The present study emphasizes that mere prevalence of Culicoides within cattle sheds does not warrant their blood feeding activity.

Amongst the different portions of cattle body, the desired landing site of the $C$. oxystoma and $C$. peregrinus were neck, hump followed by the head of the cattle (mostly in and around the ear). Although various studies suggested temperature to be a significant factor influencing the landing of Culicoides [36], our observation suggests that the thickness of skin and closeness of vascularization to body surface might be two of the most important criteria influencing the landing of female Culicoides. Likewise [35] reported on the preference of $C$. obsoletus, $C$. dewulfi, $C$. pulicaris, $C$. punctatus and $C$. nebeculosus for mane and lower legs of horse. [36] remarked that $72 \%$ of the total collections were from the belly whereas $28 \%$ from the dorsal surface. Culicoides puncticollis and $C$. schultzei preferred the belly region whereas $C$. imicola preferred the dorsal surface. A comparative preferential landing study of Culicoides on dairy cows, Shetland pony and sheep has been done [21]. It was observed that C. chiopterus favoured legs, C. punctatus, $C$. achrayi landed on the belly. Culicoides obsoletus, $C$. dewulfi and $C$. pulicaris landed on head, back and flanks respectively. Moreover $C$. chiopterus, $C$. punctatus, $C$. obsoletus/scoticus favoured the belly region of horses [37].

The difference in preferential landing could not be attributed solely to body surface temperature as there was not much difference in temperature except belly and hip, where the difference was $1^{\circ} \mathrm{C}$. However in the present study Culicoides on belly was less compared to that of neck and hump. Feeding by ectoparasitic midges on host depends on varying decree of skin thickness regionally differentiated at different body parts of host [38]. The thickness of skin in neck region of cattle was relatively less $(\sim 3.3 \mathrm{~mm})$ compared to an average $4.2 \mathrm{~mm}$ of rest of the body [39]. Minute hematophagous midges like Culicoides possess small mouthparts hence they need to feed in region with vascularization close to the body surface [38] facilitating a easy reach to blood vessels through skin

\section{Conclusion}

This investigation recorded diel activity and host-seeking activity of the potent vector species associated with cattle in the state of West Bengal. Most of the cattle sheds in West Bengal were open type and cattle were either herded in this shed or in open yard at night. In such a setup there exists a high risk of cattle being exposed to Culicoides bite during the early morning. The present study argues that in order to minimize the contact between Culicoides and cattle, the cattle should be housed in a closed shed for at least 1 hour (i.e., between $4.00 \mathrm{hr}$ and $05.00 \mathrm{hr}$ ). In closed sheds the activity of Culicoides has been observed to be reduced by 14 fold (unpublished). Owing to absence of proper closed sheds in most of the rural areas, an alternative approach could also be adopted by farmers. Blankets, badges or jute bags could be placed over the hump and neck region of the cattle during the peak activity time (between 4:00 hr and 5:00 hr) of midges thereby interfering with the preferred landing and subsequent feeding of the Culicoides midges.

\section{Declarations}

\section{ETHICS STATEMENT}

No animals were harmed during the study

AUTHORS CONTRIBUTION: First author: The entire work from data collection to data analysis and writing of manuscript. Corresponding author: Ensuring that entire process was accurate. Second and third author: Aided in insect sampling 


\section{ACKNOWLEDGEMENTS}

The authors acknowledge Head, Department of Zoology, The University of Burdwan for providing the facility to conduct the study.

\section{FINANCIAL STATEMENT}

No financial grant was received for the study

\section{COMPETING INTEREST}

The author(s) declare(s) that they have no competing interests.

\section{References}

1. Carpenter S, Mellor PS, Torr SJ. Control techniques for Culicoides biting midges and their application in the UK and northwestern Palaearctic. Med Vet Entomol. 2008; 22(3):175-187.

2. 20th Livestock Census. All India Report. Department of Animal Husbandry, Dairying and Fisheries. Government of India. 2019;https://epashuhaat.gov.in/documents/ProvisionalKeyResultsof20thLivestockCensus.pdf

3. Foxi C, Satta G, Puggioni G, Ligios C. Biting Midges(Ceratopogonidae, Culicoides). Reference Module in Biomedical Sciences. 2020; doi:10.1016/b978-0-12-818731-9.00005-7.

4. Walton TE. The history of bluetongue and a current global overview. Vet Ita. 2004; 40(3):31-38.

5. Purse BV, Carpenter S, Venter GJ, Bellis G, Mullens BA. Bionomics of temperate and tropical Culicoides midges: knowledge gaps and consequences for transmission of Culicoides-borne viruses. Annu Rev Entomol. 2015; 60:373-392.

6. Chanda MM. Understanding the epidemiology of Bluetongue virus in South India using statistical models. Ph.D Thesis, University of Oxford. 2017.

7. Chanda MM, Carpenter S, Prasad G, Sedda L, Henrys PA, Gajendragad MR, Purse BV. Livestock host composition rather than land use or climate explains spatial patterns in bluetongue disease in South India. Sci rep. 2019; 9(1): 1-15.

8. Mazumdar SM and Mazumdar A (2020) Preferential attraction of different colours of light emitting diodes for Culicoides species in West Bengal, India. Med Vet Entomol. 2020; https://doi.org/10.1111/mve.12452

9. Sapre SN. An outbreak of bluetongue in goats and sheep. Indian Vet Rev. 1964; 15:69-71.

10. Ilango K. Bluetongue virus outbreak in Tamil Nadu southern India: Need to study the Indian biting midge vectors, Culicoides Latreille (Diptera:Ceratopogonidae). Current Sci. 2006; 90(2):163-167.

11. Prasad G, Sreenivasulu D, Singh KP, Mertens PPC, Maan S. Bluetongue in the Indian subcontinent. Bluetongue (ed. by P.S. Mellor, M. Baylis and P.P.C. Mertens). Academic Press, Elsevier, Paris. 2009; p. 167-195.

12. Joardar SN, Barkataki B, Halder A, Lodh C, Sarma D. Seroprevalence of bluetongue in north eastern Indian state-Assam. Vet World. 2013;6(4):196-199.

13. Rupner RN, VinodhKumar OR, Karthikeyan R, Sinha DK, Singh KP, Dubal ZB, Shikha Tamta BS, Gupta VK, Singh BR, Malik YS, Dhama K. Bluetongue in India: a systematic review and meta-analysis with emphasis on diagnosis and seroprevalence. Veterinary Q. 2020;40(1):229-242.

14. Aurabh S, Neelam S, Sikka BK. Marketing practices of livestock products by self help groups in Burdwan District of West Bengal. Pantnagar J Res. 2010;8(1):89-96.

15. Mandal N, Mondal A, Joardar SN. Indigenous diagnostic approach for detection of bluetongue disease in West Bengal, India. Global Vet. 2011;7(3):230-233.

16. Panda M, Mondal A, Joardar SN. Seroprevalence of bluetongue virus in sheep, goat and cattle in West Bengal, India. Animal Sci Rep. 2011;5(3):105-110.

17. Harsha R, Mazumdar SM, Mazumdar A. Abundance, diversity and temporal activity of adult Culicoides spp. associated with cattle in West Bengal, India. Med Vet Entomol. 2020; doi.org/10.1111/mve.12446

18. Harrup LE, Laban S, Purse BV, Reddy YK, Reddy YN, Byregowda SM, Kumar N, Purushotham KM, Kowalli S, Prasad M, Prasad G, Bettis AA, Keyser RD, Logan J, Garros C, Gopurenko D, Bellis G, Labuschagne K, Mathieu B, Carpenter S. DNA barcoding and surveillance sampling strategies for Culicoides biting midges (Diptera: Ceratopogonidae) in southern India. Parasit Vectors. 2016;9:461.

19. Viennet E, Garros C, Rakotoarivony I, Allene X, Gardes L, Lhoir J, Fuentes I, Venail R, Crochet D, Lancelot R, Riou M, Moulia C, Baldet T, Balenghien T. Host-seeking activity of Bluetongue virus vectors: endo/exophagy and circadian rhythm of Culicoides in Western Europe. PLoS One. 2012;7(10):1-10.

20. Ayllón T, Nijhof AM, Weiher W, Bauer B, Allène X, Clausen PH. Feeding behaviour of Culicoides spp. (Diptera: Ceratopogonidae) on cattle and sheep in northeast Germany. Parasit Vectors. 2014;7(1):1-9.

21. Elbers ARW, Meiswinkel R. Culicoides (Diptera: Ceratopogonidae) and livestock in the Netherlands: comparing host preference and attack rates on a Shetland pony, a dairy cow, and a sheep. J Vector Ecol. 2015;40(2):308-317. 
22. Thompson GM, Jess S, Murchie AK. Differential emergence of Culicoides (Diptera: Ceratopogonidae) from on-farm breeding substrates in Northern Ireland. Parasitology. 2013;140(6):699-708.

23. Mazumdar SM, Harsha R, Mazumdar A. Field evaluation of locally designed ultraviolet light trap for collection of Culicoides spp. (Diptera: Ceratopogonidae). EC Vet. Sci. 2019;4(5):355-360.

24. Banerjee GC. A textbook of animal husbandry, 7th edition. Oxford and IBH publishing, New Delhi. $2018 ;$ p. 104.

25. Wirth WW, Hubert AA. The Culicoides of south east asia (Diptera: Ceratopogonidae). Mem Am Entomol Inst. 1989;44:1-508.

26. Dyce AL. The recognition of nulliparous and parous Culicoides (Diptera: Ceratopogonidae) without dissection. Aust J Entomol. 1969;8(1):11-15.

27. Dadawala Al, Biswas SK, Rehman W, Chand K, De A, Mathapati BS, Mondal B. Isolation of Bluetongue Virus Serotype 1 from Culicoides vector Captured in Livestock Farms and Sequence Analysis of the Viral Genome Segment-2. Transbound Emerg Dis. 2012;59(4):361-368.

28. Ranjan K, Prasad M, Brar B, Prasad G. First Report of Isolation of Bluetongue Virus 23 from Culicoides peregrinus Vector from India. Indian J Comp Microbiol Immunol Infect Dis. 2017;38(1):16-21.

29. Sukarsih SE, Sendow I, Bahari S, Pearce M, Daniels PW. Culicoides survey in Indonesia. Bluetongue Disease in Southeast Asia and the Pacific (ed. By T.D. St George, K. Peng, 1st edn). Australian Centre for International Agricultural Research, Canberra. 1996; p. $123-128$.

30. Mellor PS, Carpenter S, White DM. Bluetongue virus in the insect host. Bluetongue (ed. by P.S. Mellor, M. Baylis and P.P.C. Mertens). Elsevier, Paris. 2009; p. 295-320.

31. Kurogi H, Akiba K, Inaba Y, Matumoto M. Isolation of Akabane virus from the biting midge Culicoides oxystoma in Japan. Vet Microbiol. 1987;15:243-248.

32. Yanase T, Kato T, Kubo T, Yoshida K, Ohashi S, Yamakawa M, Miura Y, Tsuda T. Isolation of bovine arboviruses from Culicoides biting midges (Diptera: Ceratopogonidae) in Southern Japan: 1985-2002. J Med Entomol. 2005;42:63-67.

33. Bakhoum MT, Fall M, Fall AG, Bellis GA, Gottlieb Y, Labuschagne K, Venter GJ, Diop M, Mall I, Seck MT, Allene X. First record of Culicoides oxystoma Kieffer and diversity of species within the Schultzei group of Culicoides Latreille (Diptera: Ceratopogonidae) biting midges in Senegal. PLoS One. 2013;8(12):e84316.

34. Fall M, Diarra M, Fall A, Balenghien T, Seck MT, Bouyer J, Garros G, Gimonneau G, Allene X, Mall I, Delecolle J, Rakotoarivony I, Bakoum MT, Dusom AM, Ndao M, Konate L, Faye $\mathrm{O}$ and Baldet T. Culicoides (Diptera: Ceratopogonidae) midges, the vectors of African horse sickness virus - A host/vector contact study in the Niayes area of Senegal. Parasit Vectors. 2015;8:39.

35. Townley P, Baker KP, Quinn PJ. Preferential landing and engorging sites of Culicoides species landing on a horse in Ireland. Equine Vet J. 1984;16(2):117-120.

36. Braverman Y. Preferred landing sites of Culicoides species (Diptera: Ceratopogonidae) on a horse in Israel and its relevance to summer seasonal recurrent dermatitis (sweet itch). Equine Vet. J. 2008;20(6):426-429.

37. Elbers ARW, van den Heuvel SJ, Meiswinkel R. Diel activity and preferred landing sites in Culicoides biting midges attacking Fjord horses. Entomol Exp Appl. 2016;160(3):272-280.

38. Lehane MJ, Lehane MJ, Lehane MJ. The biology of blood-sucking in insects. Cambridge University Press, $2005 . p p 117-122$.

39. Hamid MA, Husain SMI, Khan MKI, Islam MN, Biswas MA. Skin thickness in relation to milk production of crossbred cows. Pak J Biol Sci. 2000;3(9):1525-1529.

\section{Figures}




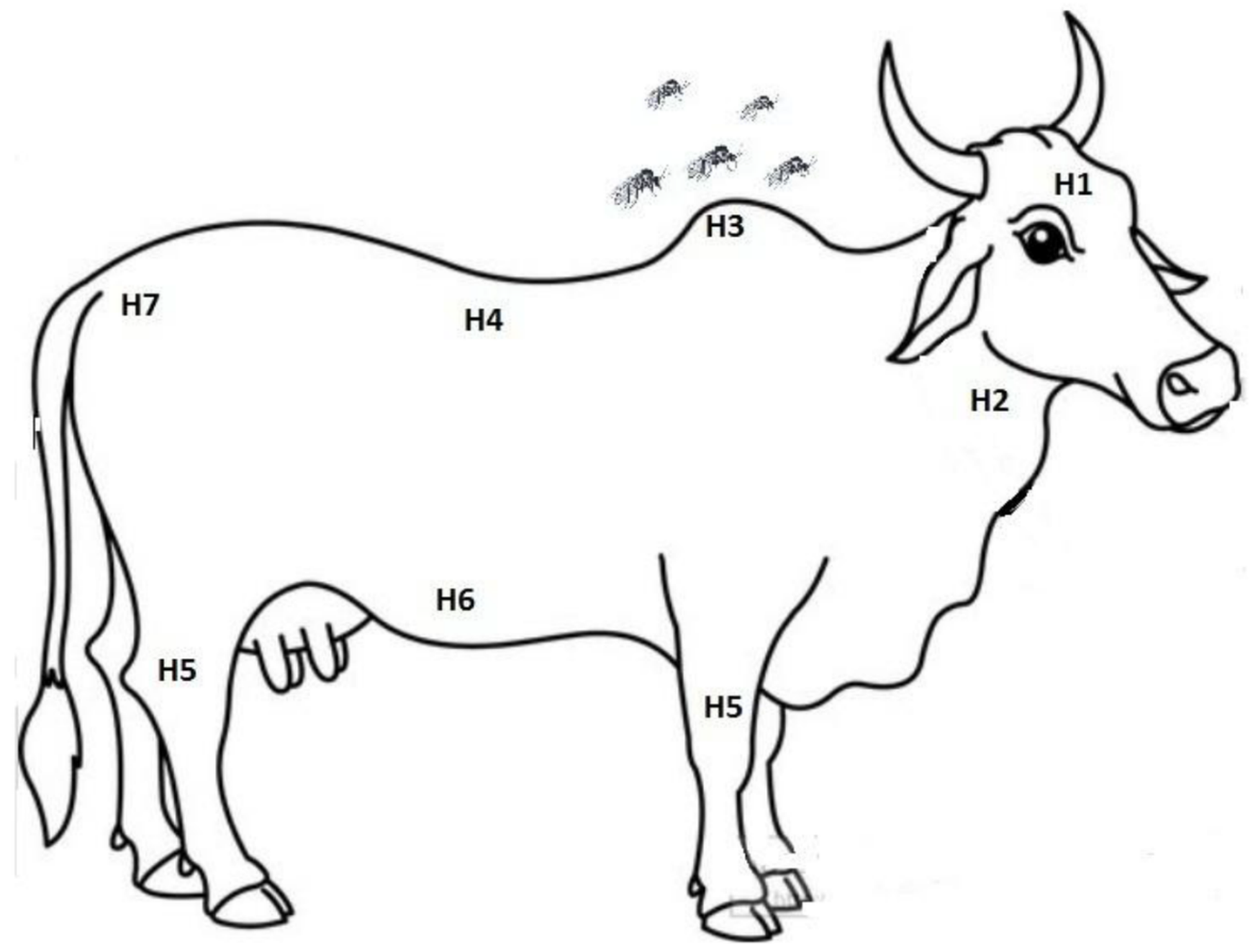

Figure 1

The body of cow was divided into head $(\mathrm{H} 1)$, neck $(\mathrm{H} 2)$, hump $(\mathrm{H} 3)$, back $(\mathrm{H} 4)$, leg $(\mathrm{H} 5)$, belly $(\mathrm{H} 6)$, hip $(\mathrm{H} 7)$ 
(a) Nulliparous

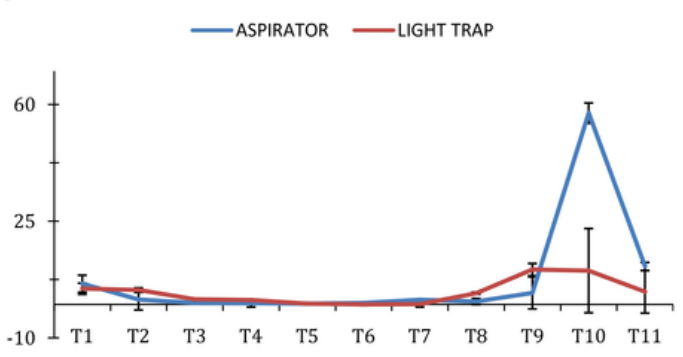

(a) Nulliparous

(b) Parous

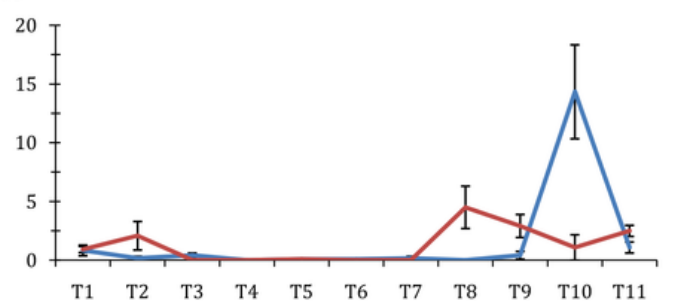

(c) Engorged

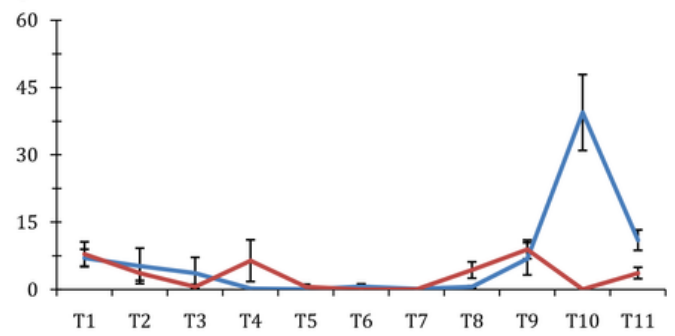

A
- ASPIRATOR $\quad$ LIGHT TRAP

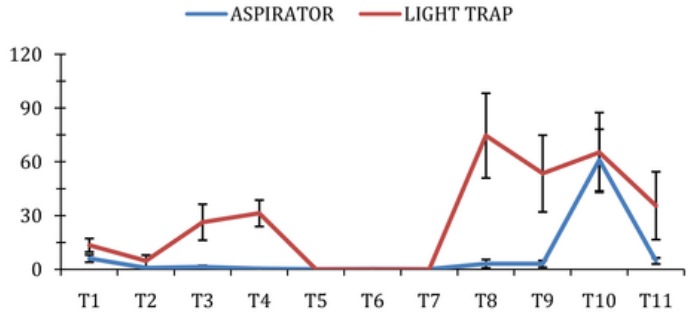

(b) Parous

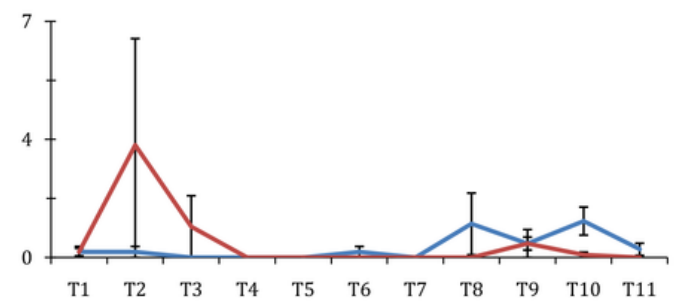

(c) Engorged

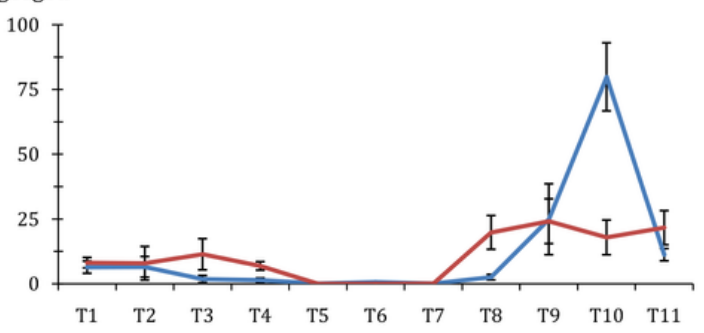

B

\section{Figure 2}

a Comparative graphical representation on sampling of Culicoides oxystoma by two trapping methods (aspirator; light trap) during May-October, 2018 from Sahebganj-Tantipara

b Comparative graphical representation on sampling of Culicoides peregrinus by two trapping methods (aspirator; light trap) during May-October, 2018 from Sahebganj-Tantipara 
(a) C. oxystoma at Dharan

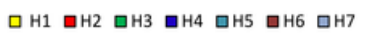

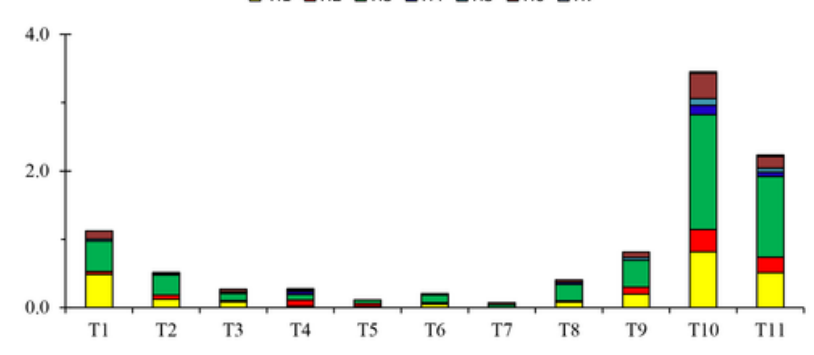

(b) C. peregrimus in Dharan

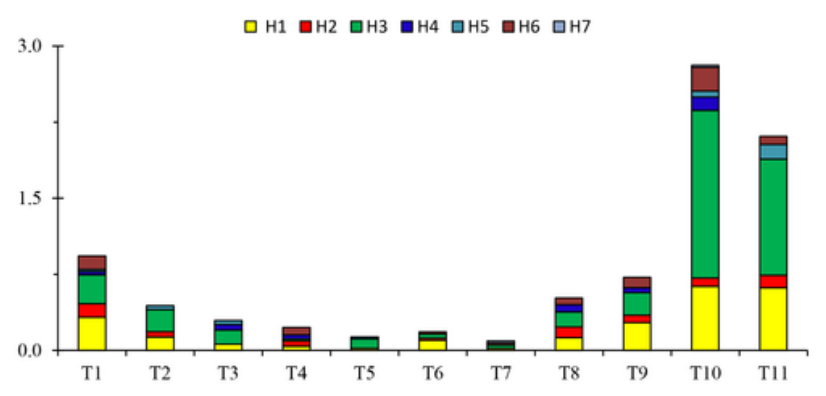

(c) C. oxystoma in Sahebganj-Tantipara

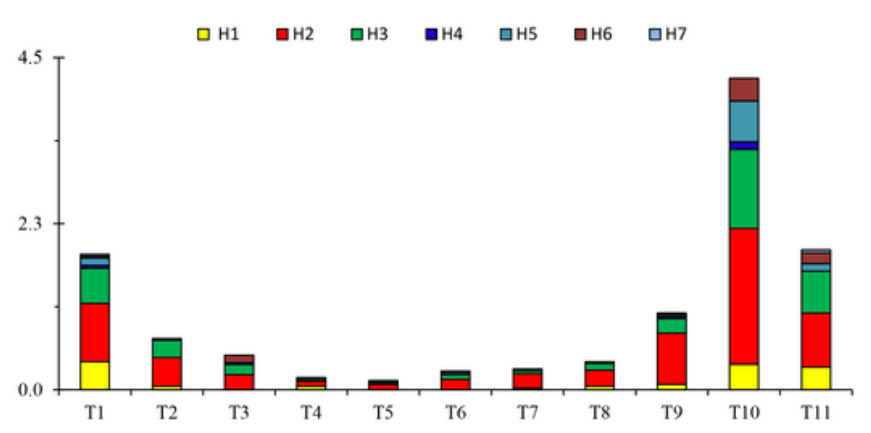

(d) C. peregrimus in Sahebganj-Tantipara

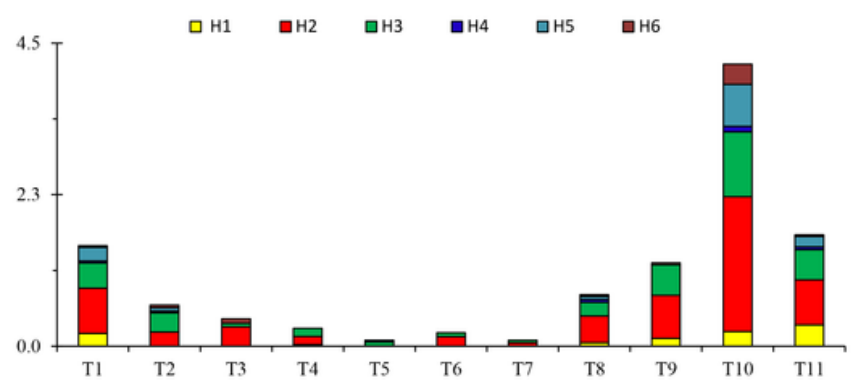

Figure 3

The graphical presentation of the landing sites at different time intervals observed against C. oxystoma and C. peregrinus as observed in Dharan and Sahebganj-Tantipara, West Bengal, India. A total of 27 nights ( 297 hours) were included for the observations in each of the sites. $\mathrm{H} 1$, head; $\mathrm{H2}$, neck; H3, hump; $H 4$, back; H5, leg; H6, belly; H7, hip. $x$ - axis: Time (in hour) T1: 18.00-19.00; T2: 19.00-20.00; T3: 20.00-21.00; T4: 21.00-22.00; T5: 23.0000.00; T6: 00.00-01.00; T7: 01.00-2.00; T8: 02.00-03.00; T9: 03.00-04.00; T10: 04.00-05.00; T11: 05.00-06.00. y-axis: mean value of log $(n+1)$ abundance of Culicoides 

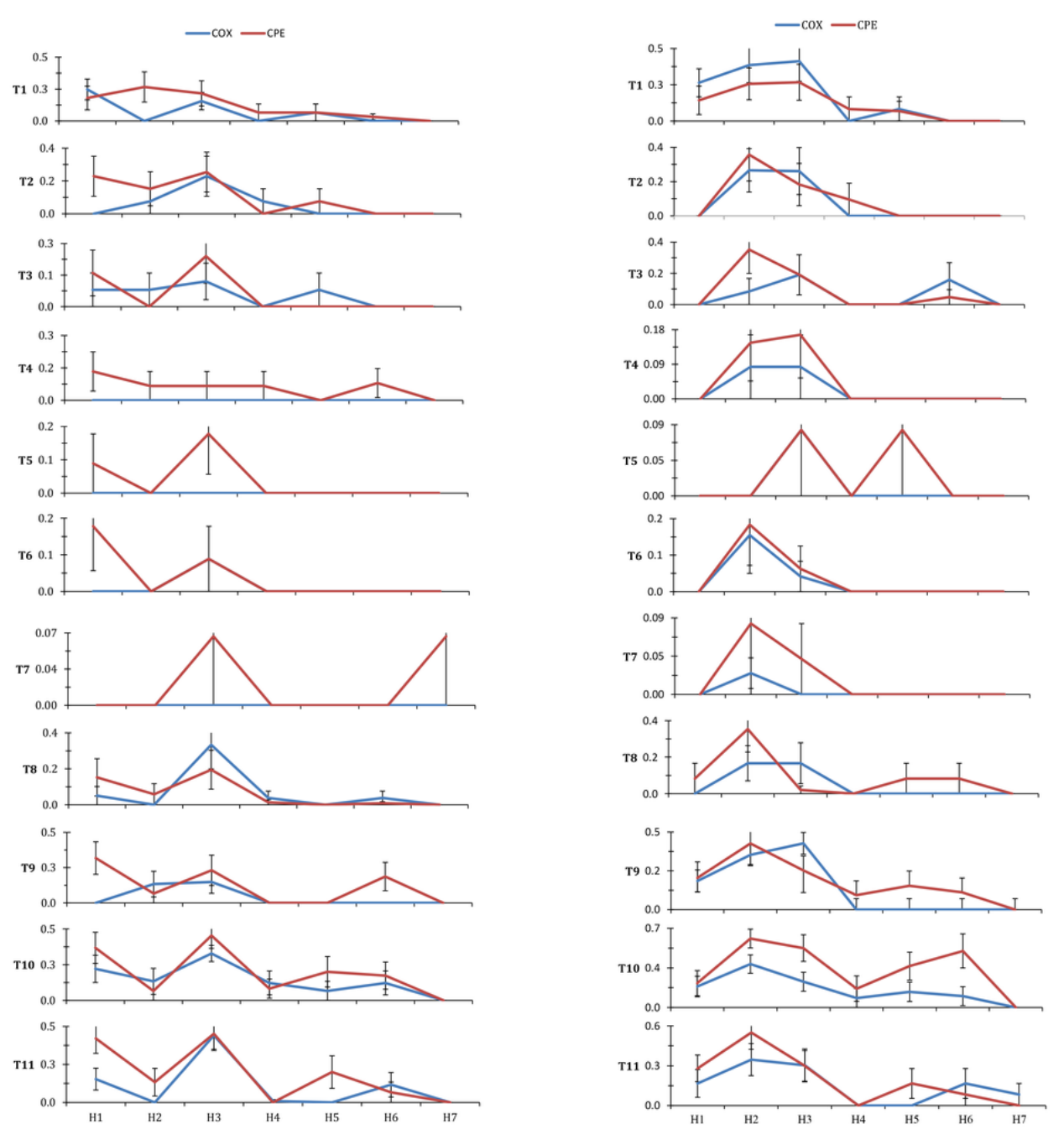

A

B

\section{Figure 4}

a. Graphical representation of proportion of engorged females of Culicoides collected from different body parts of cow at different time interval at Dharan. COX, C. oxystoma; CPE, C. peregrinus Time (in hr) T1: 18.00-19.00; T2: 19.00-20.00; T3: 20.00-21.00; T4: 21.00-22.00; T5: 23.00-00.00; T6: 00.00-01.00; T7: 01.00-2.00; T8: 02.00-03.00; T9: 03.00-04.00; T10: 04.00-05.00; T11: 05.00-06.00. x-axis: H1, head; H2, neck; H3, hump; H4, back; H5, leg; H6, belly; $H 7$, hip. $y$-axis: mean value of $\log (n+1)$ abundance of Culicoides

b. Graphical representation of the proportion of engorged females of Culicoides collected from different body parts of cow at different time interval at Sahebganj-Tantipara. COX, C. oxystoma; CPE, C. peregrinus. Time (in hr) T1: 18.00-19.00; T2: 19.00-20.00; T3: 20.00-21.00; T4: 21.00-22.00; T5: 23.0000.00; T6: 00.00-01.00; T7: 01.00-2.00; T8: 02.00-03.00; T9: 03.00-04.00; T10: 04.00-05.00; T11: 05.00-06.00. x-axis: H1, head; H2, neck; H3, hump; H4, back; $\mathrm{H} 5$, leg; $\mathrm{H6}$, belly; $\mathrm{H7}$, hip. $y$-axis: mean value of $\log (n+1)$ abundance of Culicoides

\section{Supplementary Files}

This is a list of supplementary files associated with this preprint. Click to download.

- SupplementaryTable1.docx

- SupplementaryTable2.docx

- SupplementaryTable3.docx

- SupplementaryTable4.docx 